\title{
Determinan Ketepatan Waktu Penyampaian Laporan Keuangan Perusahaan Manufaktur di Indonesia
}

Mutiara Hadi ${ }^{1}$

${ }^{2}$ Universitas Pancasila, Jl. Srengseng Sawah, Jagakarsa, Jakarta Selatan, 12640

\section{INFO ARTIKEL}

JEL Classsification:

H26

H32

Keywords:

opinion audit, publik ownership, the age of the company, timeliness.

\begin{abstract}
This research was conducted to test the effect of Audit Opinion variabels, Publik Ownership and age of the company against the Timeliness in the submission of the financial report on manufacturing company in Indonesia stock exchange period 2012-2016. The population used in this study as the object of the company is manufacturing the raw material companies were listed on the Indonesia stock exchange during the period 2012-2016 as much as 100, while the company was made the object of research (samples) that as many as 20 companies. Sample determination technique using a purposive sampling method of judgement. Hypothesis testing using a multiple regression analysis. The results showed that only the audit opinion and that influence significantly to the timeliness of the submission of the financial statements, while the age of the company but does not significantly affect the timeliness of the submission of the financial statements.
\end{abstract}

\begin{abstract}
ABSTRAK
Penelitian ini dilakukan untuk menguji pengaruh variabel Opini Audit, Kepemilikan Publik dan Umur Perusahaan terhadap Ketepatan Waktu dalam Penyampaian Laporan Keuangan pada perusahaan manufaktur di Bursa Efek Indonesia periode 2012 - 2016.Populasi yang digunakan dalam penelitian ini sebagai obyek perusahaan adalah perusahaan manufaktur bahan dasar yang terdaftar di Bursa Efek Indonesia selama periode 2012 - 2016 sebanyak 100 perusahaan, sedangkan yang dijadikan obyek penelitian (sampel) yaitu sebanyak 20 perusahaan. Teknik penentuan sampel menggunakan metode purposive judgement sampling. Pengujian hipotesis menggunakan analisis regresi linear. Hasil penelitian menunjukkan bahwa opini audit dan kepemilikan publik yang berpengaruh signifikan terhadap ketepatan waktu penyampaian laporan keuangan, sedangkan umur perusahaan berpengaruh tetapi tidak signifikan terhadap ketepatan waktu penyampaian laporan keuangan.
\end{abstract}

\section{Pendahuluan}

Perkembangan perusahaan-perusahaan go publik di Indonesia mengalami kemajuan yang pesat. Perkembangan ini mengakibatkan permintaan akan audit laporan keuangan yang semakin meningkat. Hasil audit atas perusahaan publik memiliki konsekuensi dan tanggung jawab yang besar. Adanya tanggung jawab yang besar ini memacu auditor untuk bekerja secara lebih professional. Laporan keuangan memiliki peran yang sangat penting bagi perusahaan karena laporan keuangan perusahaan berisikan informasi yang dapat digunakan dalam menilai

*Email Korespondensi: ${ }^{1}$ mutiarahadi27@yahoo.com 
kinerja perusahaan serta dapat digunakan sebagai bahan pertimbangan dalam pengambilan keputusan baik digunakan oleh perusahaan ataupun pihak yang berkepentingan. Laporan keuangan auditan adalah laporan keuangan yang telah diaudit oleh auditor. Laporan keuangan auditan memuat informasi laba yang dihasilkan oleh perusahaan yang bersangkutan dan dijadikan sebagai salah satu dasar pengambilan keputusan untuk membeli atau menjual kepemilikan yag dimiliki oleh investor. Artinya informasi laba dari laporan keuangan yang dipublikasikan akan menyebabkan kenaikan atau penurunan harga saham. Keterlambatan penyampaian laporan keuangan, secara tidak langsung juga diartikan oleh investor sebagai sinyal yang buruk bagi perusahaan.

Rachmawati (2008) mengungkapkan bahwa informasi yang diperlukan oleh pihakpihak yang berkepentingan dapat bermanfaat bilamana disajikan secara akurat dan tepat pada saat dibutuhkan oleh pemakai laporan keuangan, namun informasi tidak lagi bermanfaat bila tidak disajikan secara akurat dan tepat waktu. Nilai dari ketepatan waktu penyampaian laporan keuangan merupakan faktor penting bagi kemanfaatan laporan keuangan tersebut. Ketepatan waktu menunjukkan rentang waktu antara penyajian informasi yang diinginkan dengan frekuensi penyampaian laporan keuangan, apabila informasi tidak disampaikan dengan tepat waktu maka menyebabkan nilai dari informasi tersebut berkurang dalam pengambilan keputusan.

Setiap perusahaan yang telah terdaftar di bursa efek Indonesia berkewajiban untuk menyampaikan laporan keuangan yang disusun sesuai dengan standar akuntansi keuangan dan telah melalui proses audit oleh akuntan publik secara tepat waktu. Peraturan akan ketepatan waktu publikasi laporan keuangan ini diatur oleh Badan Pengawas Pasar Modal dan lembaga Keuangan (Bapepam LK) yang dengan UU No. 21 tahun 2011 telah diubah menjadi Otorisasi Jasa Keuangan (OJK), dengan dikeluarkannya peraturan nomor X.K.2 dalam lampiran keputusan ketua Bapepam nomor KEP-36/ $\mathrm{PM} / 2003$ tentang kewajiban penyampaian laporan keuangan berkala, peraturan ini menyatakan bahwa laporan keuangan tahunan harus disertai dengan laporan akuntan dalam rangka audit atas laporan keuangan dan harus disampaikan kepada Bapepam LK serta diumumkan kepada masyarakat paling lambat pada akhir bulan ketiga (90 hari) setelah tanggal laporan keuangan tahunan. Pada tanggal 7 Desember 2006, untuk meningkatkan kualitas keterbukaan informasi kepada publik, diberlakukan peraturan Bapepam dan LK Nomor KEP-134/BL/2006 tentang kewajiban penyampaian laporan tahunan bagi emiten dan perusahaan publik. Peraturan Bapepam dan LK nomor X.K.6 ini menyatakan bahwa dalam hal penyampaian laporan tahunan dimaksud melewati batas waktu penyampaian laporan keuangan tahunan sebagaimana diatur dalam peraturan Bapepam nomor X.K.2 maka hal tersebut diperhitungkan sebagai keterlambatan penyampaian laporan keuangan tahunan. Dengan adanya peraturan, sanksi serta lembaga yang secara independen mengatur ketepatan waktu penyampaian laporan keuangan diharapkan dapat membuat perusahaan mempublikasikan laporan keuangannya tepat waktu, namun faktanya hingga saat ini masih banyak perusahaan yang terlambat menyampaikan laporan keuangannya.

Pada pengumuman penyampaian laporan keuangan auditan yang berakhir per 31 Desember 2012 disebutkan bahwa ada 52 perusahaan yang belum menyampaikan laporan keuangan secara tepat waktu dimana hanya 3 perusahaan tercatat yang menyampaikan informasi penyebab keterlambatannya, sementara 49 perusahaan lainnya tidak menyampaikan informasi penyebab keterlambatan penyampaian laporan keuangan. Perusahaan sektor rill yang terlambat menyamapaikan laporan keuangan tahunan 2012 ada sebanyak 28 emiten dan $57 \%$ diantaranya merupakan perusahaan manufaktur (Indonesia Stock Exchannge, 2013). Pada periode 2013 terdapat 11 perusahaan manufaktur yang 
terlambat menyampaikan laporan keuangan (Indonesia Stock Exchange, 2014). BEI melaporkan terjadi peningkatan emiten yang belum menyampaikan laporan keuangan audit per Desember 2014, dari sebelumnya 49 emiten menjadi 52 emiten. BEI mencatat, 18 emiten yang belum menyampaikan laporan keuangan auditan interim 30 September 2015 dan belum membayarkan denda antara lain PT Benakat Integra Tbk (BIPI), PT Borneo Lumbung Energi dan metal Tbk (BORN), PT Berau Coal Energy Tbk (BRAU), PT Bakrie Telecom Tbk (BTEL), PT Buana Listya Tama Tbk (BULL) (www. cnnindonesia.com, 30 Juni 2016). Fenomena inilah yang menarik untuk di cermati karena ketepatan waktu penyampaian laporan keuangan merupakan salah satu pencerminan kredibilitas atau kualitas informasi yang dilaporkan dan pencerminan tingkat kepatuhan terhadap regulasi yang ditetapkan.

\section{Telaah Teori dan Pengembangan Hipotesis}

\section{Opini Audit}

Auditor adalah salah satu pihak yang memegang peranan penting untuk tercapainya laporan keuangan yang berkualitas di pasar modal. Auditor bertugas memberikan assurance terhadap kewajaran laporan keuangan yang disusun dan diterbitkan oleh manajemen perusahaan. Assurance terhadap laporan keuangan tersebut, diberikan auditor melalui opini auditor (Hilmi dan Ali, 2008).

Opini auditor terdiri dari lima jenis, yaitu wajar tanpa pegecualian (unqualified opinion), wajar tanpa pengecualian dengan kalimat penjelas (unqualified opinion with explanatory language), wajar dengan pengecualian (qualified opinion), pendapat tidak wajar (adverse opinion) dan tidak menyatakan pendapat (disclaimer opinion). Apabila auditor memberikan opini selain unqualified opinion kepada perusahaan maka itu merupakan berita buruk bagi perusahaan, hal ini akan memperlambat proses audit. Selain itu akan ada kemungkinan terjadinya konflik antara auditor dan perusahaan, sehingga bisa memperlambat publikasi laporan keuangan di Pasar Saham.

Berdasarkan teori dan penelitian sebelumnya mengenai opini auditor dan pengaruhnya terhadap ketepatan waktu penyampaian laporan keuangan sebagaimana telah dijelaskan di atas, maka dapat disusun hipotesis penelitian sebagai berikut:

\section{Kepemilikan Publik}

Dalam struktur kepemilikan bahwa pemilik perusahaan dari pihak luar mempunyai kekuatan yang besar untuk menekan manajemen dalam menyajikan informasi secara tepat waktu, karena ketepatan waktu penyampaian laporan keuangan akan mempengaruhi pengambilan keputusan ekonomi. Pemilik perusahaan dari pihak luar mempunyai kepentingan untuk mengetahui tingkat pengembalian atas investasi mereka. Oleh karena itu, mereka membutuhkan informasi yang dapat membantu pengambilan keputusan, apakah membeli, mempertahankan, atau menjual saham mereka.

Kepemilikan perusahaan oleh pihak luar mempunyai kekuatan yang besar dalam mempengaruhi perusahaan melalui media massa berupa kritikan atau komentar yang semuanya dianggap suara publik atau masyarakat. Adanya konsentrasi kepemilikan pihak luar menimbulkan pengaruh dari pihak luar sehingga mengubah pengelolaan perusahaan yang semula berjalan sesuai keinginan perusahaan itu sendiri menjadi memiliki keterbatasan. Dengan demikian, perusahaan dengan proporsi kepemilikan publik yang besar cenderung tepat waktu dalam pelaporan keuangannya.

Berdasarkan teori dan penelitian sebelumnya mengenai kepemilikan publik dan pengaruhnya terhadap ketepatan waktu penyampaian laporan keuangan sebagaimana telah dijelaskan di atas, maka dapat disusun hipotesis penelitian sebagai berikut: 


\section{Umur Perusahaan}

Umur perusahaan menjadi pertimbangan bagi investor dalam menanamkan modalnya. Perusahaan dengan umur yang makin tua, cenderung untuk lebih terampil dalam pengumpulan, pemrosesan dan menghasilkan informasi ketika diperlukan, karena perusahaan telah memperoleh pengalaman yang cukup. Selain itu perusahaan telah memiliki banyak pengalaman mengenai berbagai masalah yang berkaitan dengan pengolahan informasi dan cara mengatasinya. Perusahaan juga telah merasakan perubahan-perubahan yang terjadi selama kegiatan operasinya, sehingga perusahaan cenderung memiliki fleksibilitas dalam menangani perubahan yang akan terjadi. Hal tersebut membuat perusahaan mampu menyampaikan laporan keuangan lebih tepat waktu.

\section{Metode Penelitian}

Populasi dalam penelitian ini adalah perusahaan-perusahaan manufaktur yang terdaftar di Bursa Efek Indonesia dari selama tahun 2012 sampai dengan 2016. Pengambilan sampel dalam penelitian ini menggunakan teknik purposive sampling. Purposive sampling merupakan teknik pengambilan sampel dengan menggunakan kriteria-kriteria yang telah ditentukan. Adapun kriteria-kriteria penentuan sampel yang digunakan dalam penelitian ini adalah sebagai berikut:

1. Perusahaan Manufaktur yang terdaftar di Pasar Saham secara berturut-turut untuk periode 2012, 2013, 2014, 2015 dan 2016;

2. Perusahaan tersebut telah menerbitkan laporan keuangan tahunan untuk periode 2012, 2013, 2014, 2015 dan 2016;

3. Memiliki data tanggal penyampaian laporan keuangan tahunan ke Bapepam untuk periode 2012, 2013, 2014, 2015 dan 2016;

4. Menampilkan data dan informasi yang digunakan untuk menganalisis faktorfaktor yang mempengaruhi ketidaktepatan waktu dalam penyampaian laporan keuangan untuk periode 2012, 2013, 2014, 2015 dan 2016.

Berdasarkan kriteria tersebut diperoleh sampel sebanyak 183 sampel yang terdiri dari 183 perusahaan. Pengujian dilakukan dengan uji regresi berganda terditi dari uji model (uji F) dan uji hipotesis menggunakan uji t. Koefisien determinasi (R-square) digunakan untuk menguji kemampuan menjelasan variabel independen terhadap ketepatan waktu laporan keuangan.

Definisi Operasional dan pengukuran yang digunakan dalam penelitian ini diikhtisarkan sebagai berikut.

Tabel 1. Operasionalisasi Variabel

\begin{tabular}{|c|c|c|c|c|}
\hline No & Variabel & Definisi & Pengukuran & Acuan \\
\hline 1 & $\begin{array}{l}\text { Opini Audit } \\
\text { (OA) }\end{array}$ & $\begin{array}{l}\text { Opini akuntan; pendapat } \\
\text { akuntan mengenai } \\
\text { laporan keuangan yang } \\
\text { dibuat oleh manajemen }\end{array}$ & $\begin{array}{l}\text { skor dummy, dimana } \\
\text { perusahaan yang } \\
\text { memperoleh jenis pendapat } \\
\text { unqualified opinion maupun } \\
\text { jenis WTP dengan paragraf } \\
\text { penjelasan, diberi kode } 1 . \\
\text { Sedangkan perusahaan yang } \\
\text { memperoleh selain pendapat } \\
\text { WTP maupun WTP dengan } \\
\text { paragraf penjelasan, diberi } \\
\text { kode } 0\end{array}$ & $\begin{array}{l}\text { Fathini dan } \\
\text { Atikah, (2007) }\end{array}$ \\
\hline
\end{tabular}




\begin{tabular}{|c|c|c|c|c|}
\hline No & Variabel & Definisi & Pengukuran & Acuan \\
\hline 2 & $\begin{array}{l}\text { Kepemilikan } \\
\text { Publik (KP) }\end{array}$ & $\begin{array}{l}\text { kepemilikan masyarakat } \\
\text { umum (bukan institusi } \\
\text { yang signifikan) terhadap } \\
\text { saham perusahaan publik }\end{array}$ & $\begin{array}{ll}\text { Kepemilikan } & \text { Publik = } \\
\text { Presentase } & \text { Kepemilikan } \\
\text { Publik } & \end{array}$ & Saputra (2016) \\
\hline 3 & $\begin{array}{l}\text { Umur } \\
\text { Perusahaan } \\
\text { (UP) }\end{array}$ & $\begin{array}{l}\text { umur perusahaan dihitung } \\
\text { dari tanggal listed-nya di } \\
\text { pasar modal }\end{array}$ & $\begin{array}{l}\text { Akhir tahun tutup buku - } \\
\text { tanggal listed perusahaan }\end{array}$ & Kadir (2011) \\
\hline 4 & $\begin{array}{l}\text { Ketepatan } \\
\text { Waktu (KW) }\end{array}$ & $\begin{array}{l}\text { Ketepatan waktu diukur } \\
\text { dengan menggunakan } \\
\text { hitungan jumlah hari } \\
\text { penyampaian laporan } \\
\text { keuangan tahunan } \\
\text { auditan ke Bapepam }\end{array}$ & $\begin{array}{l}\text { Perusahaan dikategorikan } \\
\text { terlambat apabila laporan } \\
\text { keuangan disampaikan } \\
\text { lewat dari tanggal } 31 \text { Maret } \\
\text { (melebihi waktu } 90 \text { hari dari } \\
\text { tanggal tutup buku tahunan). }\end{array}$ & Sulistyo, (2010) \\
\hline
\end{tabular}

Teknik analisis yang dipakai untuk menjawab permasalahan dan menguji hipotesis yang telah dikemukakan adalah menggunakan teknik analisis regresi linear. Adapun persamaan regresi dalam penelitian ini dituliskan sebagai berikut.

$$
\mathrm{Y}=\mathrm{b}_{0}+\mathrm{b}_{1} \mathrm{X}_{1}+\mathrm{b}_{2} \mathrm{X}_{2}+\mathrm{b}_{3} \mathrm{X}_{3}+\mathrm{e}
$$

Keterangan:

$\mathrm{Y}=$ Ketepatan waktu penyampaian laporan keuangan $(\mathrm{KW})$

$\mathrm{b}_{1 . . .} \mathrm{b}_{3}=$ Koefisien Regresi

$\mathrm{X}_{1}=$ Opini Auditor (OA)

$\mathrm{X}_{2}=$ Kepemilikan publik (KP)

$\mathrm{X}_{3}=$ Umur Perusahaan (UP)

$\mathrm{e}=$ Error

\section{Analisis Hasil dan Pembahasan}

Penelitian inin bertujuan untuk menguji pengaruh opini auditor (OA), kepemilikan publik (KP) dan umur perusahaan (UP) terhadap ketepatan waktu (KW) pemyampaian laporan keuangan. Deskruipsi variabel menunjukkan rata-rata penyerahan laporan auditan adalah 86 hari kerja setelah tahun tutup buku. Namun ada perusahaan yang menyerahkan terlambat sampai dengan 100 hari kerja. Opini audit diukur dalam 2 kelompok, wajar tanpa pengecualian dan lainnya. Mayoritas sampel mendapatakan opini wajar tanpa pengecualian. Kepemilikan publik rata-rata $23 \%$, sedangkan umur perusahaan ratarata telah terdaftar di bursa efek selama lebih dari 15 tahun.

Tabel 2. Hasil Statistik Deskriptif

\begin{tabular}{lllll}
\hline Statistik Deskriptif & KW & OA & KP & UP \\
\hline Mean & 86,510 & 0,940 & 23,272 & 19,346 \\
Maximum & 100 & 1 & 51,41 & 34,25 \\
Minimum & 69,000 & 0.000 & 1,000 & 1,99 \\
Std. Deviation & 5,682 & 0,238 & 13,433 & 7,379 \\
\hline
\end{tabular}

Sumber :www.idx.co.id (Data diolah 
Pengujian hipotesis dengan uji regrsi menghasilkan hasil uji model, hasil uji pengaruh masing-masing variabel untuk membuktuikan hipotesis, dan kemampuan variabel independen menjelaskan variabel dependen. Hasil pengujian menunjukkan bahwa opini audit dan kepemilikan publik berpengaruh terhadap ketepatan waktu, sementara umur perusahaan tidak berpengaruh. Kemampuan independen variabel menjelaskan ketepatan waktu adalah sebesar $12,2 \%$ artinya lebih dari $80 \%$ ketepatan waktu dipengaruhi oleh faktor lain diluar model yang diteliti.
Perusahaan yang mampu mendapatkan opini audit dengan pendapat wajar tanpa pengecualian (unqualified opinion) cenderung akan lebih tepat waktu dalam pelaporan keuangan karena pendapat wajar tanpa pengecualian (unqualified opinion) merupakan berita baik (good news) dari auditor. Sebaliknya, perusahaan akan cenderung tidak tepat waktu dalam menyampaikan laporan keuangannya apabila menerima opini selain wajar tanpa pengecualian (unqualified opinion) karena hal tersebut dianggap sebagai berita buruk (bad

Tabel. Hasil Pengujian

\begin{tabular}{lrrrc}
\hline Keterangan & \multicolumn{1}{c}{ B } & Std. Error & t-hitung & \multicolumn{1}{c}{ Sig. } \\
\hline Opini Auditor & 0,994 & 1,006 & 3,223 & 0,002 \\
Kepemilikian Publik & 0,908 & 1,102 & 2,306 & 0,023 \\
Umur Perusahaan & 0,911 & 1,098 & 1,104 & 0,272 \\
Constant & 84,840 & 0,000 & & \\
R-Square & 0,149 & & & \\
Adjusted R-Square & 0,122 & & & \\
F-hitung & 5,600 & & & \\
Sig. F & 0.010 & & & \\
\hline
\end{tabular}

Pengaruh Opini Audit terhadap Ketepatan Waktu Penyampaian Laporan Keuangan

Hasil pengujian hipotesis dengan menggunakan uji t pada variabel Opini Audit (OA) yang diukur dengan kategori 1 untuk unqualified opinion dan kategori 0 untuk selain unqualified opinion berhasil membuktikan pengaruh opini audit terhadap kemungkinan ketepatan waktu penyampaian laporan keuangan. Hal ini terlihat bahwa opini audit mempunyai koefisien positif sebesar 3.223 dengan tingkat signifikansi $0,002<0,05$ yang berarti hipotesis pertama $\left(\mathrm{H}_{1}\right)$ dalam penelitian ini diterima yang menyatakan opini audit berpengaruh signifikan terhadap kemungkinan ketepatan waktu penyampaian laporan keuangan. Dengan demikian dapat dinyatakan bahwa opini audit memotivasi manajemen untuk menyampaikan laporan keuangan secara tepat waktu kepada pihak-pihak yang berkepentingan. news).

Hal ini didukung oleh fakta yang terjadi pada sampel penelitian yaitu pada PT. Indofood CBP Sukses Makmur, Tbk pada tahun 2012 perusahaan tersebut mendapatkan pendapat wajar tanpa pngecualian (unqualified opinion) dimana perusahaan itu tepat waktu dalam menyampaikan laporan keuangannya ke Bapepam yaitu pada tanggal 28 Maret 2013 (menyampaikan laporan keuangannya kurang dari 90 hari setelah tanggal laporan keuangan tahunan atau sebelum tanggal 31 Maret). Dibandingkan dengan PT. Siantar Top, Tbk yang pada tahun 2013 mendapatkan pendapat selain wajar tanpa pngecualian (unqualified opinion) dimana perusahaan itu tidak tepat waktu dalam menyampaikan laporan keuangannya ke Bapepam yaitu pada tanggal 02 April 2014 (menyampaikan laporan keuangannya lebih dari 90 hari setelah tanggal laporan keuangan 
tahunan atau setelah tanggal 31 Maret). Sehingga opini audit suatu perusahaan mempengaruhi kemungkinan ketepatan waktu penyampaian laporan keuangan kepada publik. Hasil penelitian ini sejalan dengan penelitian yang dilakukan Putra dan Putra (2016), Yusralaeni, dkk (2010) dan Meiden (2007) yang menyatakan bahwa opini audit berpengaruh signifikan terhadap kemungkinan ketepatan waktu penyampaian laporan keuangan. Hasil penelitian tidak sejalan dengan temuan Verawati dan Wirakusuma (2016). Pada perkembangannya, Ramantha (2017 menjadikan opini audit sebagai variable pemoderasi.

\section{Pengaruh Kepemilikan Publik terhadap Ketepatan Waktu Penyampaian Laporan Keuangan}

Hasil pengujian hipotesis dengan menggunakan uji t pada variabel kepemilikan publik (KP) yang diukur dengan melihat saham yang dimiliki oleh publik berhasil membuktikan pengaruh kepemilikan publik terhadap ketepatan waktu penyampaian laporan keuangan. Hal ini terlihat bahwa kepemilikan publik mempunyai koefisien positif sebesar 2.306 dengan tingkat signifikansi $0.023<0,05$ yang berarti hipotesis kedua $\left(\mathrm{H}_{2}\right)$ dalam penelitian ini diterima. Dimana pada hipotesis penelitian menyatakan bahwa kepemilikan publik berpengaruh signifikan terhadap kemungkinan ketepatan waktu penyampaian laporan keuangan. Dapat diartikan kepemilikan publik berkapasitas banyak atau sedikit menjamin ketepatan waktu penyampaian laporan keuangan (timeliness) dari perusahaan tersebut.

Hal ini didukung oleh fakta yang terjadi pada sampel penelitian yaitu pada tahun 2016 PT. Ultrajaya Milk Industry, Tbk merupakan perusahaan dengan proporsi kepemilikan publik yang besar dengan total saham yang dimiliki publik adalah 51,41\% memiliki ketepatan waktu penyampaian laporan keuangan yaitu menyampaikan laporan keuangannya ke Bapepam pada tanggal 31 Maret2016, sedangkan pada tahun 2012 PT. Taisho Pharmaceutical Indonesia, Tbk merupakan perusahaan dengan proporsi kepemilikan publik sejumlah $1 \%$ dan perusahaan itu tidak tepat waktu (terlambat) dalam menyampaikan laporan keuangannya ke Bapepam yaitu pada tanggal pada tanggal 1 April 2013. Hasil penelitian ini sejalan dengan penelitian yang dilakukan oleh sanjaya dan Wirawati (2017), Sulistyo dan Syafrudin (2010), Dwiyanti (2010), dan Kadir (2016) yang menyatakan bahwa kepemilikan publik berpengaruh signifikan terhadap kemungkinan ketepatan waktu penyampaian laporan keuangan.

\section{Pengaruh Umur Perusahaan terhadap Ketepatan Waktu Penyampaian Laporan Keuangan \\ Hasil pengujian hipotesis dengan} menggunakan uji $t$ pada variabel umur perusahaan (UP) yang diukur dengan tanggal listed perusahaan di pasar modal. Tidak berhasil membuktikan pengaruh umur perusahaan terhadap ketepatan waktu penyampaian laporan keuangan. Hal ini terlihat bahwa umur perusahaan mempunyai koefisien sebesar 1.104 dengan tingkat signifikansi $0,272>$ 0,05 yang berarti hipotesis ketiga $\left(\mathrm{H}_{3}\right)$ dalam penelitian ini ditolak. Dimana pada hipotesis penelitian menyatakan bahwa umur perusahaan berpengaruh signifikan terhadap kemungkinan ketepatan waktu penyampaian laporan keuangan. Pada kenyataannya tidak demikian, perusahaan yang memiliki umur lebih tua tidak menjamin ketepatan waktu penyampaian laporan keuangan dari perusahaan tersebut.

Hal ini didukung oleh fakta yang terjadi pada sampel penelitian yaitu pada tahun 2012 PT. Taisho Pharmaceutical Indonesia, Tbk merupakan perusahaan yang memiliki umur lebih tua yaitu 30.19 tahun memiliki ketepatan waktu penyampaian laporan keuangan yaitu menyampaikan laporan keuangannya ke Bapepam pada tanggal 26 Maret 2013, sedangkan pada tahun 2012 PT. Indofarma, Tbk yang juga merupakan perusahaan yang 
memiliki umur lebih tua haan yakni adalah 22,03 tahun namun perusahaan itu tepat waktu dalam menyampaikan laporan keuangannya ke Bapepam yaitu pada tanggal 15 Maret 2013. Fakta selanjutnya, pada tahun 2012 PT. Martina Berto, Tbk merupakan perusahaan yang memiliki umur lebih muda dengan umur yang dimiliki perusahaan tersebut adalah 1,99 tahun memiliki ketepatan waktu penyampaian laporan keuangan yaitu menyampaikan laporan keuangannya ke Bapepam pada tanggal 30 Maret 2013. Sehingga dalam hal ini menunjukkan bahwa tua atau mudanya umur perusahaan tidak menjamin kemungkinan perusahaan tersebut memiliki ketepatan waktu dalam menyampaikan laporan keuangannya.

Pada dasarnya ketepatan waktu dipengaruhi oleh seberapa besar rasa tanggung jawab suatu perusahaan dalam mematuhi peraturan yang telah ditetapkan oleh Bapepam tentang keterbukaan informasi, terutama mengenai ketepatan waktu penyampaian laporan keuangan (timeliness) sehingga pihak-pihak yang berkepentingan mengetahui kondisi perusahaan tersebut terlepas perusahaan itu berskala besar maupun kecil. Hasil penelitian ini sejalan dengan penelitian yang dilakukan oleh Yusralaini, dkk (2010), Wirakusuma (20130, Kadir (2016), dan Wahyu (2014) dan Astuti (2007) yang menyatakan bahwa umur perusahaan berpengaruh tidak signifikan terhadap kemungkinan ketepatan waktu penyampaian laporan keuangan.

\section{Simpulan, Keterbatasan, dan Implikasi Hasil Penelitian}

Opini audit berpengaruh signifikan terhadap ketepatan waktu penyampaian laporan keuangan. Artinya adalah perusahaan yang menerima opini unqualified opinion cenderung akan lebih tepat waktu dalam penyampaian laporan keuangannya. Unqualified opinion merupakan berita baik bagi perusahaan, sehingga hal tersebut tidak menjadi penghalang bagi perusahaan untuk mempublikasikan laporan keuangannya. Sesuai dengan analisis data yang telah dilakukan, maka peneliti menarik kesimpulan sebagai berikut:

Perusahaan sebaiknya memeperhatikan faktor-faktor yang dapat mempengaruhi ketepatan waktu penyampaian laporan keuangan terutama opini auditor. Apabila auditor memberikan opni unqualified opinion kepada perusahaan maka itu merupakan berita baik (good news). Dan sebaliknya, apabila auditor memberikan opini selain unqualified opinion kepada perusahaan maka itu merupakan berita buruk bagi perusahaan, hal ini akan memperlambat proses audit dan akan adanya kemungkinan terjadinya konflik antara auditor dan perusahaan, sehingga dapat memperlambat publikasi laporan keuangan di pasar saham.

Peneliti berikutnya memperluas atau menambah variabel bebasnya seperti profitabilitas, DER, Reputasi KAP, ukuran perusahaan, likuiditas, serta leverage keuangan. Dan menambah sampel yang digunakan, dimana tidak hanya terfokus pada satu industry dan data penelitian lebih beragam. Pemegang saham sebaiknya menganalisis lebih jauh mengenai opini audit yang diberikan oleh auditor kepada perusahaan. Kepemilikan publik berpengaruh signifikanterhadapketepatan waktupenyampaian laporan keuangan. Artinya adalah semakin besar persentase kepemilikan publik maka akan semakin besar juga publik untuk mempengaruhi perusahaan berupa kritikan ataupun komentar yang membuat pengelolaan perusahaan yang semula lancar menjadi terhambat sehingga penyampaian laporan keuangan menjadi lama.

Penelitian ini belum mejelaskan lebih banyak faktor mengenai penyebab keterlambatan penyampaian keuangan ke Bapepam. Oleh karena itu peneliti berikutnya diharapkan dapat memperluas atau menambah faktor lainnya seperti profitabilitas, DER, Reputasi KAP, ukuran perusahaan, likuiditas, serta leverage keuangan. Dan menambah sampel yang digunakan, dimana tidak hanya terfokus pada satu industry dan data penelitian lebih beragam. 


\section{Daftar Pustaka}

Astuti, C. D. (2007). Faktor-faktor yang berpengaruh terhadap ketepatan waktu pelaporan keuangan. Jurnal Informasi, perpajakan, akuntansi dan keuangan publik, 2(1), 27-42.

Badan Pengawas Pasar Modal (1996). Keputusan Ketuan Badan Pengawas Pasar Modal dan Lembaga Keuangan, NO.80/PM1996 tentang Kewajiban Penyampaian Laporan Keuangan Berkala.

Dwiyanti, R., \& Ardiyanto, M.D. (2010). Analisis faktor-faktor yang mempengaruhi ketepatan waktu pelaporan keuangan pada perusahaan manufaktur yang terdaftar di Bursa Efek Indonesia(Doctoral dissertation, Universitas Diponegoro).

Hilmi, F.H.U. (2008). Analisis faktor-faktor yang mempengaruhui ketepatan waktu penyampaian laporan keuangan:: Studi empiris pada perusahaan-perusahaan yang terdaftar di BEJ periode 20042006 (Doctoral dissertation, Universitas Gadjah Mada).

Kadir,A. (2016). Faktor-faktor yang berpengaruh terhadap ketepatan waktu pelaporan keuangan studi empiris pada perusahaan manufaktur di bursa efek Jakarta. Jurnal Manajemen dan Akuntansi, 12(1).

Meiden, W. C. (2007). Variabel Total Lag Laporan Keuangan Perusahaan Manufaktur di BEJ". Jurnal Akuntabilitas, 7(1), 18-22.

Peraturan Badan Pengawasan Pasar Modal dan Lembaga Keuangan. (2008). www. bapepam.go.id

Putra, P. G. O. S., \& Putra, I. M. P. D. (2016). Ukuran Perusahaan sebagai Pemoderasi Pengaruh Opini Auditor, Profitabilitas, dan Debt to Equity Ratio terhadap Audit Delay. E-Jurnal Akuntansi, 2278-2306.

Rachmawati. Sistya. (2008). Pengaruh Faktor Internal dan Eksternal Perusahaan Delay dan Timeliness. Jurnal Akuntansi dan Keuangan, Vol, 10, No. 1.
Ramantha, I. W. (2017). Pengaruh Profitabilitas dan Ukuran Perusahaan terhadap Ketepatan Waktu Pelaporan Keuangan dengan Opini Audit sebagai Variabel Pemoderasi. E-Jurnal Akuntansi, 15921620.

Sanjaya, I. M. D. M., \& Wirawati, N. G. P. (2016). Analisis faktor-faktor yang mempengaruhi ketepatan waktu pelaporan keuangan pada perusahaan manufaktur yang terdaftar di BEI. E-Jurnal Akuntansi, 17-26.

Saputra. (2016). Analisis Faktor-Faktor yang Mempengaruhi Ketepatan Waktu Penyampaian Laporan Keuangan ke Publik Study pada Perusahaan Property dan Real Estate yang

Sulistyo, W. A. N., \& Syafruddin, M. (2010). Analisis Faktor-Faktor yang Berpengaruh Terhadap Ketepatan Waktu Penyampaian Laporan Keuangan pada Perusahaan yang Listing di Bursa Efek Indonesia Periode 2006-2008 (Doctoral dissertation, Universitas Diponegoro).

Verawati, N. M.A., \& Wirakusuma, M. G. (2016). Pengaruh Pergantian Auditor, Reputasi Kap, Opini Audit, dan Komite Audit dalam Audit Delay. E-Jurnal Akuntansi, 1083-1111.

Wirakusuma, M. T. M. G. (2013). Faktorfaktor yang memengaruhi ketepatwaktuan penyampaian laporan keuangan. E-Jurnal Akuntansi, 15-31.

Yusralaini, A. R., \& Yusralaini, LD (2010). Analisis Faktor-faktor yang Mempengaruhi Ketepatan Waktu Penyampaian Laporan Keuangan ke Publik pada Perusahaan yang Terdaftar di BEI (2005-2007). Jurnal Ekonomi, 18(2). 